\title{
In Vivo $\mathrm{T1}$ of Blood Measurements in Children with Sickle Cell Disease Improve Cerebral Blood Flow Quantification from Arterial Spin-Labeling MRI
}

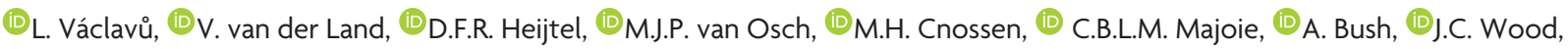 \\ $\mathbb{D}_{\text {K.J. Fijnvandraat, }}$ H.J.M.M. Mutsaerts, and $\mathbb{1}^{\text {A.J. N. Nederveen }}$
}

\begin{abstract}
BACKGROUND AND PURPOSE: Children with sickle cell disease have low hematocrit and elevated CBF, the latter of which can be assessed with arterial spin-labeling MR imaging. Quantitative CBF values are obtained by using an estimation of the longitudinal relaxation time of blood ( $T_{\text {blood }}$ ). Because $T_{\text {blood }}$ depends on hematocrit in healthy individuals, we investigated the importance of measuring $T_{\text {blood }}$ in vivo with MR imaging versus calculating it from hematocrit or assuming an adult fixed value recommended by the literature, hypothesizing that measured $\mathrm{Tl}_{\text {blood }}$ would be the most suited for $\mathrm{CBF}$ quantification in children with sickle cell disease.

MATERIALS AND METHODS: Four approaches for $\mathrm{T}_{\text {blood }}$ estimation were investigated in 39 patients with sickle cell disease and subsequently used in the CBF quantification from arterial spin-labeling MR imaging. First, we used $1650 \mathrm{~ms}$ as recommended by the literature ( $\Pi_{\text {blood }}$-fixed); second, $T_{\text {blood }}$ calculated from hematocrit measured in patients ( $\Pi_{\text {blood }}$-hematocrit); third, $\Pi_{\text {blood }}$ measured in vivo with a

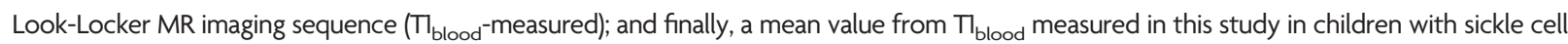
disease ( $\Pi_{\text {blood }}$-sickle cell disease). Quantitative flow measurements acquired with phase-contrast MR imaging served as reference values for CBF.

RESULTS: $\mathrm{Tl}_{\text {blood }}$-measured (1818 $\pm 107 \mathrm{~ms}$ ) was higher than the literature recommended value of $1650 \mathrm{~ms}$, was significantly lower than $T_{\text {blood }}$-hematocrit (2058 $\left.\pm 123 \mathrm{~ms}, P<.001\right)$, and, most interesting, did not correlate with hematocrit measurements. Use of either $T_{\text {blood }}$-measured or $T_{\text {blood }}$-sickle cell disease provided the best agreement on CBF between arterial-spin labeling and phase-contrast MR imaging reference values.
\end{abstract}

CONCLUSIONS: This work advocates the use of patient-specific measured $T_{\text {blood }}$ or a standardized value (1818 ms) in the quantification of CBF from arterial spin-labeling in children with SCD.

ABBREVIATIONS: $\mathrm{ASL}=$ arterial spin-labeling; $\mathrm{Hct}=$ hematocrit; $\mathrm{PCASL}=$ pseudocontinuous $\mathrm{ASL} ; \mathrm{PC}-\mathrm{MRI}=$ phase-contrast $\mathrm{MR}$ imaging; $\mathrm{SCD}=$ sickle cell disease; $T_{\text {blood }}=$ longitudinal relaxation time of blood

$\mathbf{S}$ ickle cell disease (SCD) is associated with a considerable risk of stroke, ${ }^{1}$ which is reduced by blood transfusion therapy ${ }^{2}$ and identified by screening blood flow velocities in intracranial arteries with transcranial Doppler. ${ }^{3}$ Additionally, microvascular tissue perfusion, or $\mathrm{CBF}$, is also increased in patients with $\mathrm{SCD}^{4,5}$; which is related to low hematocrit (Hct). ${ }^{6,7} \mathrm{CBF}$ measurements are in-

Received December 15, 2015; accepted after revision February 24, 2016.

From the Department of Radiology (L.V., D.F.R.H., C.B.L.M.M., H.J.M.M.M., A.J.N.), Academic Medical Center, Amsterdam, the Netherlands; Department of Pediatric Hematology (V.v.d.L., K.J.F.), Emma Children's Hospital, Academic Medical Center, Amsterdam, the Netherlands; C.J. Gorter Center for High Field MRI (M.J.P.v.O.), Department of Radiology, Leiden University Medical Center, Leiden, the Netherlands; Department of Pediatric Hematology (M.H.C.), Erasmus University Medical Center-Sophia Children's Hospital, Rotterdam, the Netherlands; Department of Biomedical Engineering (A.B.), Viterbi School of Engineering, University of Southern California, Los Angeles, California; Department of Pediatrics (J.C.W.), Children's Hospital Los Angeles, Los Angeles, California; and Sunnybrook Research Institute (H.J.M.M.M.), Toronto, Ontario, Canada.

Patients were recruited and scanned by V.v.d.L., H.J.M.M.M., and D.F.R.H.; the study was designed by K.J.F. and A.J.N. The data were analyzed by L.V. and H.J.M.M.M, and the final manuscript was drafted, reviewed, and edited by all authors. strumental in understanding the pathophysiology of impaired perfusion in the occurrence of silent cerebral infarcts in SCD. ${ }^{4,8,9}$ Noninvasive CBF measurements can be performed with arterial spin-labeling (ASL) and a quantification model to calculate physiological $\mathrm{CBF}$ values. The wide range of $\mathrm{CBF}$ values reported in the literature in $\mathrm{SCD}^{1,4,9}$ emphasizes the need for either more accurate estimates or direct measurements of the often-assumed parameters required for $\mathrm{CBF}$ quantification models.

The longitudinal relaxation time of the blood $\left(\mathrm{Tl}_{\mathrm{blood}}\right) \mathrm{pa}-$ rameter accounts for the decay of the ASL signal with time, and

This work was funded by the Dutch NutsOhra Foundation, Amsterdam, the Netherlands (grant 1303-055).

Paper previously presented, in part, at: Annual Meeting of the International Society for Magnetic Resonance in Medicine Benelux, January 16, 2015; Ghent, Belgium Please address correspondence to Lena Václavů, MSc, Department of Radiology, Z0-178, Academic Medical Center, Meibergdreef 9, 1105 AZ, Amsterdam, the Netherlands; e-mail: I.vaclavu@amc.uva.nl

$\sum \Delta$ Indicates article with supplemental on-line photo.

http://dx.doi.org/10.3174/ajnr.A4793 
inaccurate estimates of $\mathrm{T} 1_{\text {blood }}$ could result in over- or underestimation of CBF. ${ }^{10-12}$ For healthy adults, with a stable Hct, a fixed $\mathrm{T} 1_{\text {blood }}$ value of $1650 \mathrm{~ms}$ is recommended for CBF quantification from pseudocontinuous ASL (pCASL) at $3 \mathrm{~T} .{ }^{13,14} \mathrm{~T} 1_{\text {blood }}$ is inversely correlated with $\mathrm{Hct},{ }^{10,13,15-19}$ and a linear relationship has been proposed in the literature permitting the calculation of $\mathrm{T} 1_{\text {blood }}$ from measured Hct values. ${ }^{12,13,16}$ While Hct ranges from $38 \%$ to $45 \%$ in healthy children, ${ }^{20}$ it is as low as $18 \%-30 \%$ in children with SCD. ${ }^{21}$ Hence, if measured Hct values are available, $\mathrm{T} 1_{\text {blood }}$ can be derived accordingly. However, recent studies suggest that $\mathrm{T} 1_{\text {blood }}$ may additionally differ in children with SCD. ${ }^{12,22,23}$

Owing to recent developments in MR imaging, direct measurements of the inversion recovery of $\mathrm{T} 1_{\text {blood }}$ are now possible by combining a global inversion pulse and a subsequent sectionselective Look-Locker readout in the sagittal sinus. ${ }^{16,17}$ Patientspecific, in vivo $\mathrm{T} 1_{\text {blood }}$ measurements are noninvasive, robust, and fast, making them preferable to calculating $\mathrm{T}_{\text {blood }}$ from blood samples. Our first hypothesis was that in vivo-measured $\mathrm{T} 1_{\text {blood }}$ would be higher in children with SCD than the adult reference value of $1650 \mathrm{~ms}$ due to anemia. We also considered that conformational changes inherent to sickle red blood cells may produce additional unforeseen changes in $\mathrm{T}_{\text {blood }}{ }^{12}$ We investigated the importance of measuring patient-specific differences in $\mathrm{T}_{\text {blood }}$ for the accuracy of ASL quantification in patients with SCD. We hypothesized that patient-specific $\mathrm{Tl}_{\text {blood }}$ values acquired in vivo would improve CBF quantification in SCD compared with CBF quantification with $\mathrm{T}_{\text {blood }}$ calculated from $\mathrm{Hct}$ or $\mathrm{T}_{\mathrm{blood}}$-fixed at $1650 \mathrm{~ms}$.

The aim of this study was to determine which of the following $4 \mathrm{~T}_{\text {blood }}$ derivatives would provide the best CBF quantification compared with quantitative reference $\mathrm{CBF}$ values measured with 2D phase-contrast MR imaging (PC-MRI): 1) literature-recommended adult $\mathrm{T} 1_{\text {blood }}$ of $1650 \mathrm{~ms},{ }^{14}$ 2) $\mathrm{T} 1_{\text {blood }}$ calculated from Hct, 3 ) in vivo-measured $\mathrm{T} 1_{\text {blood }}$, or 4 ) a fixed average SCD value from the mean $\mathrm{T} 1_{\text {blood }}$ measured in vivo in this study.

\section{MATERIALS AND METHODS}

Experiments were performed according to principles of the Declaration of Helsinki, and the study was approved by the local institutional review board at the Academic Medical Center, Amsterdam, the Netherlands.

\section{Patients}

Eligible children were approached prospectively from 2 outpatient clinics as described previously. ${ }^{24}$ Informed consent was obtained from parents or guardians and children older than 12 years of age. Inclusion criteria were $\mathrm{HbSS}$ or $\mathrm{HbS} \beta^{0}$ genotypes and 8-17 years of age. Exclusion criteria were a history of stroke, stenosis of the intracranial arteries and velocity of $>155 \mathrm{~cm} / \mathrm{s}$ on transcranial Doppler imaging, current chronic blood transfusion therapy, bone marrow transplant, MR imaging contraindications, and major concomitant health problems. Patients were in a steady-state of SCD, without evidence of infection or sickle cell crisis up to 1 month before participation.

\section{Hematocrit}

Venous blood samples were drawn from an antecubital vein on the day of the MR imaging assessment and processed according to
Table 1: Demographic and clinical characteristics

\begin{tabular}{lc}
\hline Demographic or Clinical Parameter & Mean and SD \\
\hline Total No. & 39 \\
Females (No. and \% of total) & $16(41 \%)$ \\
Males (No. and \% of total) & $23(59 \%)$ \\
Age (yr) & $12 \pm 2$ \\
Hematocrit (\%) & $23 \pm 3$ \\
Hemoglobin (g/d/L) & $8.4 \pm 1.1$ \\
Hemoglobin F (\%) & $10 \pm 6$ \\
Hemoglobin A2 (\%) & $4.8 \pm 1$ \\
Hemoglobin S (\%) & $84 \pm 5$ \\
Mean corpuscular volume (mL) & $82 \pm 10$ \\
Mean corpuscular hemoglobin & $21 \pm 0.6$ \\
\multicolumn{2}{c}{ concentration (mmol/L) } \\
\hline
\end{tabular}

a Normal range reference values: $\mathrm{Hb}=10-16$.

${ }^{\mathrm{b}} \mathrm{HbF}<1 \%$.

${ }^{\mathrm{c}} \mathrm{HbA2}=2-3$.

${ }^{\mathrm{d}} \mathrm{MCV}=75-95$.

e $\mathrm{MCHC}=19.0-22.5$.

standard procedures in the hospital laboratory. Hct values were used to calculate $\mathrm{T} 1_{\text {blood }}$-Hct values.

\section{MR Imaging Acquisition}

Thirty-two children underwent $3 \mathrm{~T}$ imaging on an Intera scanner (Philips Healthcare, Best, the Netherlands) with an 8-channel head coil, and due to a scanner upgrade, the remaining 8 children were scanned at $3 \mathrm{~T}$ on an Ingenia (Philips Healthcare) with a 15-channel head coil. The protocol included 3D-TOF MRA, 2D T2-weighted, $\mathrm{T} 1_{\text {blood }}, 2 \mathrm{D}$ pseudocontinuous ASL, and 2D phase-contrast sequences.

The $\mathrm{T} 1_{\text {blood }}$ acquisition section was planned perpendicular to the posterior sagittal sinus ${ }^{16}$ and comprised a multi time-point inversion recovery experiment. This technique uses a global inversion pulse followed by a series of $95^{\circ}$ section-selective readout pulses, which are intended to saturate the tissue surrounding the sinus. Assuming complete replenishment of inverted blood between 2 consecutive pulses, a high contrast is achieved between tissue and blood, allowing the detection of the inversion recovery of blood. A nonselective adiabatic $180^{\circ}$ inversion pulse (hyperbolic secant pulse, $\mathrm{B} 1$ value/duration of the pulse $=13.5 \mathrm{mT} / 13$ $\mathrm{ms}$ ) preceded a single section Look-Locker EPI readout (flip angle, $95^{\circ}$; voxel size, $1.5 \times 1.5 \mathrm{~mm}$; matrix, $240 \times 240 \mathrm{~mm}$; section thickness, $2 \mathrm{~mm}$; TE/TR, 15/10,000 ms; TI, $200 \mathrm{~ms}$; $\Delta$ TI, $150 \mathrm{~ms}$; 60 readouts; 6 signal averages; scan duration, 1 minute 20 seconds).

A gradient-echo single-shot EPI pCASL sequence was used to acquire perfusion-weighted images (75 subtracted label-control pairs; resolution, $3 \times 3 \times 7 \mathrm{~mm}$; FOV, $240 \times 240 \mathrm{~mm}$; 17 continuous axial sections; TE/TR, 17/4000 ms; flip angle, $90^{\circ}$; labeling duration, $1650 \mathrm{~ms}$; postlabeling delay, $1525 \mathrm{~ms}$; background suppression, 1680 and $2830 \mathrm{~ms}$ after a prelabeling saturation pulse; scan duration, 10 minutes 7 seconds).

Quantitative flow measurements were obtained with a nontriggered 2D single-section PC-MRI acquisition in the internal carotid and vertebral arteries. Imaging parameters were the following: FOV, $230 \times 230 \mathrm{~mm}$; voxel size, $0.45 \times 0.45 \mathrm{~mm}$; TR/TE, $15 / 5 \mathrm{~ms}$; flip angle, $15^{\circ}$; maximum velocity-encoding, $140 \mathrm{~cm} / \mathrm{s}$; section thickness, $4 \mathrm{~mm}$; scan duration, 1 minute. 

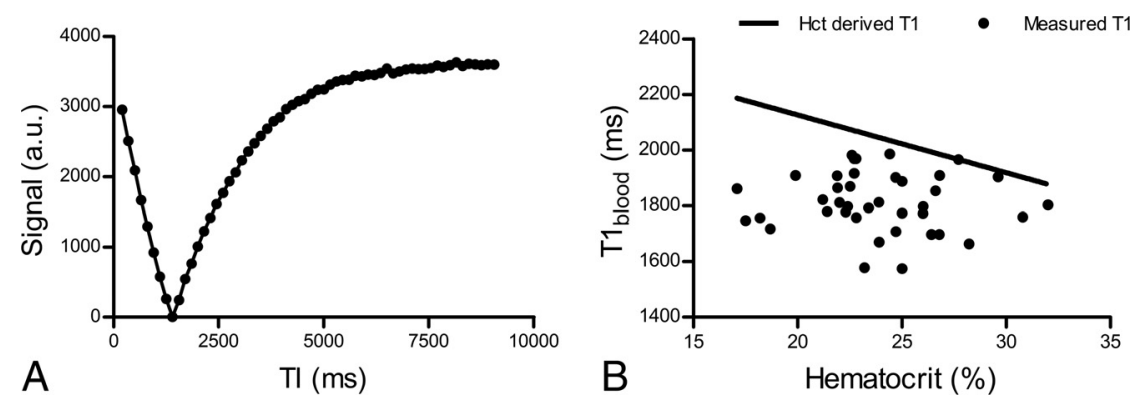

FIG 1. $A$, Representative inversion recovery of the venous $T \prod_{\text {blood }}$ signal acquired in the sagittal sinus in a child with sickle cell disease. $B$, In vivo-measured $\mathrm{Tl}_{\text {blood }}$ values are significantly lower than Hct-derived $T_{\text {blood }}$ values. $T l_{\text {blood }}$-measured does not correlate with patient hematocrit (mean Hct, 23\% $\pm 3 \%$ ) (Pearson $r=0.02, P=.89 ; n=39$ ).

Table 2: $\mathrm{Tl}_{\mathrm{b}} \mathrm{bood}$ values and corresponding $\mathrm{CBF}$ values quantified from ASL

\begin{tabular}{cccc}
\hline $\mathrm{Tl}_{\text {blood }}$ & Method (Value) & $\begin{array}{c}\text { ASL-CBF } \\
\text { (mL/100 g/min) }\end{array}$ & $\begin{array}{c}\boldsymbol{P} \\
\text { Value }\end{array}$ \\
\hline $\mathrm{T}_{\text {blood }}$-fixed & Literature (1650 ms) & $114 \pm 13$ & $<.05$ \\
$\mathrm{Tl}_{\text {blood }}$-Hct & $\begin{array}{c}\text { Calculated from patient's } \\
\text { hematocrit (variable) }\end{array}$ & $95 \pm 10$ & $<.05$ \\
$\mathrm{~T}_{\text {blood }^{-}}$ & $\begin{array}{c}\text { Measured with MR in vivo in } \\
\text { measured } \\
\text { patients with SCD (variable) }\end{array}$ & $106 \pm 14$ & $\mathrm{NS}$ \\
$\mathrm{T}_{\text {blood }}-\mathrm{SCD}$ & $\begin{array}{c}\text { Mean of } \mathrm{Tl}_{\text {blood }} \text {-measured } \\
\text { (1818 ms) }\end{array}$ & $105 \pm 12$ & $\mathrm{NS}$ \\
\hline
\end{tabular}

Note:-NS indicates not significant.

a Repeated-measures ANOVA was performed to test the significance $(P$ in the final column) of differences between CBF from ASL and reference CBF obtained from phase-contrast MRI flow measurements.

\section{Data Postprocessing}

$\mathrm{Tl}_{\text {blood. }}$ Blood-filled voxels within the sagittal sinus were selected on the basis of the highest signal intensity. Voxel values were subsequently averaged, and the data were fitted to a 3-parameter model (Nealder-Mead method; MathWorks, Natick, Massachusetts), with the parameters $M_{0}$, Offset, and $\mathrm{T} 1_{\text {blood, }}{ }^{17}$ and solved for $\mathrm{T} 1_{\text {blood }}$ :

1) $M(n T I)=a b s\left(M_{0} \times\right.$

$$
\left.\left[1-2 \times \exp \left(-\frac{\text { Offset }+T I_{1}+(n T I-1) \times \Delta T I}{T 1_{\text {blood }}}\right)\right]\right),
$$

where $M$ models the T1 recovery from the data, $n T I$ is the readout number, $a b s$ denotes the absolute values, $M_{0}$ is the net magnetization, "Offset" accounts for imperfect inversion, $T I_{1}$ is $200 \mathrm{~ms}$, and $\Delta T I$ is the sampling interval (150 ms). The sum of squared errors of the final (optimal) iteration after solving the Nealder-Mead function indicated how well the data fitted the model and served as a quality check.

Cerebral Blood Flow. Raw pCASL data were processed as described previously ${ }^{25}$ by using a processing pipeline for the registration and quantification of the data. A 2-compartment quantification model was used, as published in detail previously ${ }^{9,26}$ (except that the equilibrium magnetization of arterial blood was derived from the $M_{0}$ of CSF multiplied by the blood-water partition coefficient, ${ }^{27}$ and labeling efficiency was 0.7 ). The $\mathrm{T} 1_{\text {blood }}$ parameter was adjusted for each CBF quantification as follows: first, adult fixed $\mathrm{T}_{\text {blood }}$ of $1650 \mathrm{~ms}$ taken from literature ${ }^{13}$; second, patient-specific Hct-calculated $\mathrm{T}_{\text {blood }}$ values ${ }^{16}$; third, patient-specific in vivo-measured $\mathrm{T} 1_{\text {blood }}$ obtain total flow (milliliters per minute). Total flow was then divided by brain mass (gram), which was calculated from the product of the volume (estimated from segmented anatomic images in SPM8; http://www.fil.ion.ucl.ac.uk/spm/software/spm12) and an assumed brain density of $1.05 \mathrm{~g} / \mathrm{L},{ }^{28}$ to obtain PC-MRI $\mathrm{CBF}$ in milliliters $/ 100 \mathrm{~g} / \mathrm{min},{ }^{29}$ which served as the reference value for $\mathrm{CBF}^{22,29}$

\section{Statistical Analysis}

A Pearson correlation was performed between $\mathrm{T} 1_{\text {blood }}$-measured and Hct. Repeated-measures ANOVA was used to test the statistical significance of the differences among the 5 CBF quantification methods: 1) CBF ( $1_{\text {blood }}$-fixed at $\left.\left.1650 \mathrm{~ms}\right), 2\right) \mathrm{CBF}$ $\left.\left(\mathrm{T} 1_{\text {blood }}-\mathrm{Hct}\right), 3\right) \mathrm{CBF}\left(\mathrm{T}_{\text {blood }^{-}}\right.$-measured in vivo, 4$) \mathrm{CBF}\left(\mathrm{T}_{\text {blood }^{-}}\right.$ SCD fixed at the average measured value), and 5) PC-MRI reference CBF. Paired $t$ tests were used to test the statistical significance of individual group differences post hoc. Agreement between PC-MRI and the 4 ASL methods was investigated with linear regression and Bland-Altman analyses in Matlab (MathWorks, Natick, Massachusetts). Linear regression analysis was performed to show agreement between PC-MRI and the 4 CBF quantification methods from ASL. Bland-Altman analysis was performed to indicate the bias corresponding to over- or underestimation of the ASL CBF method compared with the PC-MRI method. The limits of agreement (dotted lines) indicate the $95 \%$ confidence intervals.

\section{RESULTS}

Demographic and clinical characteristics are summarized in Table 1. One patient's $\mathrm{T}_{\text {blood }}$ scan was discarded due to poor image quality, so the mean CBF values from pCASL are based on 39 datasets. For PC-MRI, only 33 datasets were of sufficient quality to quantify reference CBF.

\section{Measured $\mathrm{TI}_{\text {blood }}$}

The mean Hct was $23 \% \pm 3 \%$ for 39 children. The mean $\mathrm{T}_{\text {blood }^{-}}$ measured value was $1818 \pm 107 \mathrm{~ms}$, which was significantly lower than mean $\mathrm{T}_{\text {blood }}$-Hct values $(2045 \pm 69 \mathrm{~ms}$; paired $t$ test, $P<.001$ ) but higher compared to the fixed adult value of $1650 \mathrm{~ms}^{\mathrm{T}} \mathrm{T}_{\mathrm{blood}^{-}}$ measured was not significantly different between scanners ( $t$ test, $P=$ .94). Figure $1 A$ shows a representative inversion recovery curve from 1 patient as a function of the sum of least-squares fit. The sum of squared errors from fitting the $\mathrm{T} 1_{\text {blood }}$-measured values to the model is shown in On-line Fig 1. $\mathrm{Tl}_{\mathrm{blood}^{-}}$-measured values did not correlate 

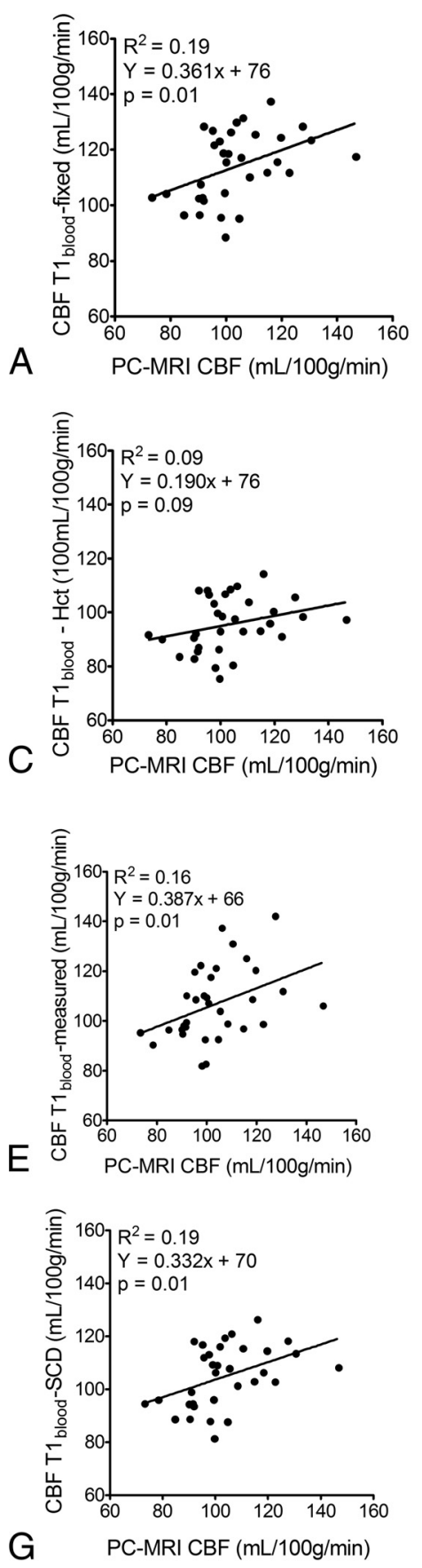
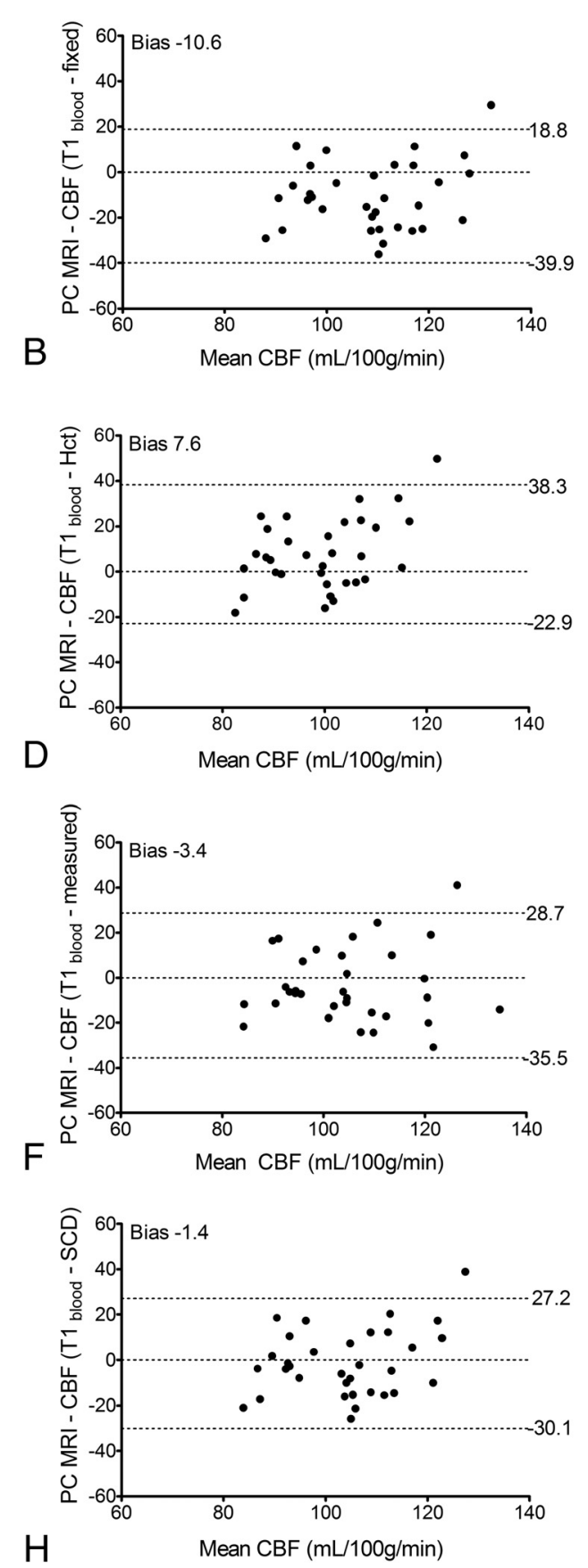

FIG 2. Linear regression and Bland-Altman plots between CBF values measured with PC-MRI and ASL, which was quantified by using 4 different $\Pi_{\text {blood }}$ values: a fixed literature value of $1650 \mathrm{~ms}$ (CBF $\Pi_{\text {blood }}$-fixed) ( $A$ and $\left.B\right) ; \Pi_{\text {blood }}$ calculated from hematocrit (CBF $\left.\Pi_{\text {blood }}-\mathrm{Hct}\right), \Pi=0.5^{\star} \mathrm{Hct}+0.37$ (C and $D)^{16}$; in vivo-measured $\prod_{\text {blood }}\left(C B F T_{\text {blood }}\right.$-measured) $(E$ and $F)$; and a fixed SCD value obtained from the mean of the in vivo-measured $\Pi_{\text {blood }}\left(C B F T_{\text {blood }}-S C D\right)(G$ and $H)$. The left panel shows linear regressions (solid line), and the right panel shows the mean on the $x$-axis versus the difference on the $y$-axis between PCASL and PC-MRI CBF with limits of agreement (dotted lines above and below) $(n=33)$.

with Hct values measured from blood samples $(r=0.02, P=.89$; Fig $1 B)$ or with age $(r=0.03, P=.85)$ and did not differ significantly between males and females ( $t$ test, $P=.37$ ).

\section{Cerebral Blood Flow}

Four CBF quantification methods were compared with PCMRI CBF, the results of which are summarized in Table 2. Linear regression analyses between PC-MRI and pCASL CBF are shown in the left panel of Fig 2 and reveal slopes significantly different from zero for all CBF quantifications except for the $\mathrm{T} 1_{\text {blood }}$-Hct CBF quantification. The Bland-Altman plots in the right panel of Fig 2 show the bias and limits of agreement for the mean and the difference between the measurements. $\mathrm{T} 1_{\text {blood }}$-fixed overestimated $\mathrm{CBF}$ and $\mathrm{T} 1_{\text {blood }}$-Hct underestimated CBF, while the individual in vivo $\mathrm{T} 1_{\mathrm{blood}^{-}}$-measured values and mean $\mathrm{T} 1_{\text {blood }}-\mathrm{SCD}$ value provided the best agreement with PC-MRI values, both on an absolute level, revealed by no significant difference between PCMRI and CBF in the repeated-measures ANOVA analysis (Table 2), but also on a one-to-one basis, as demonstrated in the linear regression plots (Fig 2). A representative example of CBF maps quantified with $\mathrm{T}_{\text {blood }^{-}}$ measured from 2 patients is shown in Fig 3.

\section{DISCUSSION}

We demonstrate that in vivo-measured venous $\mathrm{Tl}_{\text {blood }}$ values in children with SCD were higher than the literature-recommended $1650 \mathrm{~ms}$, were not significantly correlated with measured Hct, and were lower than the Hct-derived values for $\mathrm{T} 1_{\text {blood }}$ CBF quantified with in vivo-measured $\mathrm{T}_{\text {blood }}$ provided better agreement with PC-MRI reference measurements than CBF quantified with fixed adult $\mathrm{T} 1_{\text {blood }}$ and Hct-derived T1 $1_{\text {blood }}$

\section{$\mathbf{T 1}_{\text {blood }}$ and Hematocrit}

Previous literature suggests that healthy children 6-18 years of age (assuming a stable Hct of $40 \%-45 \%$ ) have $\mathrm{T} 1_{\text {blood }}$ values between 1680 and 1880 ms. ${ }^{18}$ In this study, in patients with a much lower Hct than healthy children, we measured $\mathrm{T} 1_{\text {blood }}$ values closer to the upper range of the literature-reported $\mathrm{T} 1_{\text {blood }}$ values. ${ }^{18}$ Yet, our $\mathrm{T} 1_{\text {blood }}$ values were lower than expected, considering the low Hct values obtained from our patients' blood samples. It is unlikely that we underestimated $\mathrm{T} 1_{\text {blood }}$ due to sequence-related limitations because the Look-Locker T1 technique has previously provided robust results in the same ROI. ${ }^{16,17,27}$

Reports of $\mathrm{T} 1_{\text {blood }}$ values ranging from 1500 to $2100 \mathrm{~ms}$ follow a linear relationship with Hct between $23 \%$ and $50 \% .{ }^{13,16,18}$ It is possible that we did not have sufficient precision to detect this inverse relationship in our dataset or that the range of Hct values 


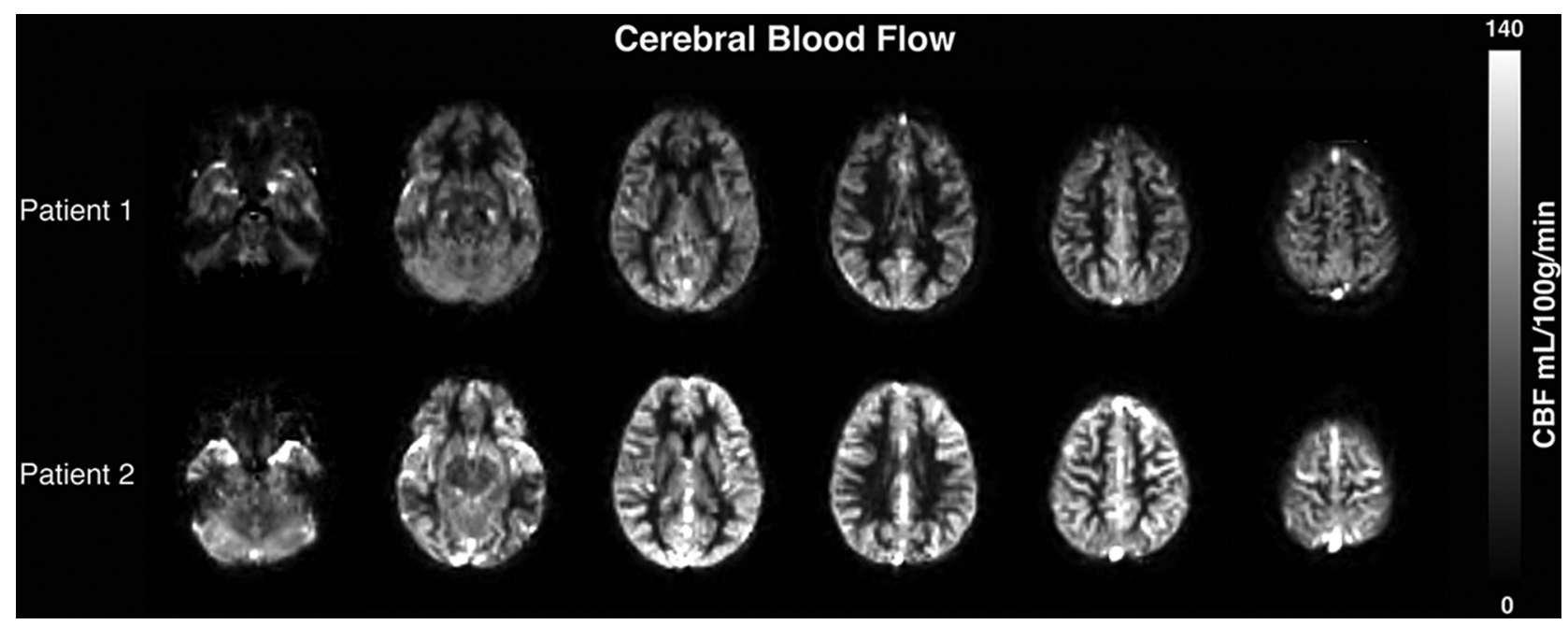

FIG 3. Axial brain sections showing CBF from 2 representative examples of 2 fourteen-year-old boys with SCD. The upper row shows a patient with low CBF and the lower row shows a patient with high CBF.

was too narrow in our patients $(17 \%-32 \%)$. Abnormalities in SCD blood, other than low Hct, may account for the incongruity between $\mathrm{T} 1_{\text {blood }}$ and Hct measured here. While we did not measure blood rheology, abnormalities such as decreased red blood cell deformability, increased aggregation, and increased viscosity have been demonstrated consistently. ${ }^{21,30-34}$ Furthermore, red blood cells in SCD exhibit different membrane properties and viscosity, which may have reduced $\mathrm{T} 1_{\text {blood }}$ due to shrinkage of cells and therefore lower water content. ${ }^{35}$

\section{CBF Quantification}

Our CBF results fall within the large range of reported values in children with SCD ( 70-150 mL/100 g/min). ${ }^{1,4,9,36,37}$ The necessary reliance on a quantification model for obtaining physiologically meaningful CBF values means that the method is sensitive to the assumptions of the model used, which could differ between healthy adults and children with SCD. The fact that measured $\mathrm{T} 1_{\text {blood }}$ ameliorates the CBF quantification but Hct-calculated $\mathrm{T} 1_{\text {blood }}$ does not opposes the use of Hct-corrected CBF quantification in SCD and, instead, advocates the use of measured $\mathrm{T} 1_{\text {blood }}$. $\mathrm{T} 1_{\text {blood }}$ measurements are advantageous over Hct-calculated $\mathrm{T} 1_{\text {blood }}$ because they are faster ( 1 minute 20 seconds) and less invasive. In the absence of $\mathrm{T} 1_{\text {blood }}$ measurements, we propose using a mean value of $1818 \mathrm{~ms}$, as measured in this study in children with SCD, which would suffice in improving the absolute agreement with PC-MRI for CBF quantification from ASL.

\section{Limitations}

This study should be considered in light of the technical limitations of the $\mathrm{T} 1_{\text {blood }}$ measurement and the potentially inaccurate reference flow measurements from PCMR.

Whereas $\mathrm{T} 1_{\text {blood }}$ measurements were acquired in venous blood, the quantification model requires arterial estimates. However, because we compared venous $\mathrm{T} 1_{\text {blood }}$ measurements with $\mathrm{T} 1_{\text {blood }}$ values derived from venous Hct, the potential mismatch would have been similar for both methods. Moreover, we demonstrate that the measured venous $\mathrm{T} 1_{\text {blood }}$, used to quantify $\mathrm{CBF}$, improved the agreement with independently acquired flow measurements in arterial vessels with PC-MRI, which shows that although the arterial measurement may be better, the venous measurement is sufficient.

PC-MRI as a surrogate for CBF could be critiqued for CBF overestimation due to partial volume effects ${ }^{38}$ and inaccurate brain density estimates or underestimated flow due to noncardiac-triggered acquisition. Still, recent literature suggests that errors in flow values associated with nontriggered 2D PC-MRI are $<3 \%$ compared with triggered acquisitions. ${ }^{29,39}$ Despite these limitations, a recent study has shown high agreement (intraclass correlation coefficient, 0.73) between PC-MRI and pCASL, ${ }^{40}$ emphasizing that PC-MRI is currently the best noninvasive reference for pCASL CBF.

\section{CONCLUSIONS}

Inaccurate $\mathrm{T} 1_{\text {blood }}$ estimates can be a major confounder for quantitative perfusion assessment from ASL. Patient-specific, in vivomeasured $\mathrm{T} 1_{\text {blood }}$ measurements provided more accurate $\mathrm{CBF}$ values than $\mathrm{T}_{\text {blood }}$ derived from $\mathrm{Hct}$ values. To avoid overestimation of CBF in SCD, we recommend the use of a fixed value of $1818 \mathrm{~ms}\left(\mathrm{~T}_{\text {blood }} \mathrm{SCD}\right)$ for CBF quantification from ASL in SCD if measured $\mathrm{T} 1_{\text {blood }}$ values are not available.

\section{ACKNOWLEDGMENTS}

The authors thank the participants and the medical and technical staff who helped with recruitment, scanning, and blood measurements.

Disclosures: Lena Václavů—RELATED: Grant: Fonds NutsOhra (grant from Dutch Sickle Cell Research Foundation).* Dennis F.R. Heijtel—UNRELATED: Employment: Philips Healthcare (currently employed). Matthias J.P. van Osch-UNRELATED: Employment: Philips Healthcare; Patents (planned, pending or issued): joint patent with Philips Healthcare* and a joint patent with the Florey Institute of Neuroscience and Mental Health (Melbourne, Australia) and Lund University (Sweden), ${ }^{*}$ both pending; Other: research support by Philips Healthcare. ${ }^{\star}$ Charles B.L.M. Majoie-UNRELATED: Payment for Lectures (including service on Speakers Bureaus): Stryker.* John C. Wood-UNRELATED: Consultancy: BioMed Informatics, ApoPharma, Isis Pharmaceuticals, Pfizer, Celgene, WorldCare Clinical; Grants/Grants Pending: National Institutes of Health (1U01HL117718-01 from the National Heart, Lung, and Blood Institute), ${ }^{*}$ National Institutes of Health National Institute of Diabetes and Digestive and Kidney Diseases (1R01DK097115-01A1)*; Payment for Development of Educational Presentations: American Society of Hematology; Other: Philips Healthcare, ${ }^{*} \mathrm{Com}$ ments: Work-in-Kind-Philips provided technical expertise, pulse sequences, and engineering staff and we have tested new MRI techniques, product feedback, and academic productivity (abstracts and papers). *Money paid to the institution. 


\section{REFERENCES}

1. Helton KJ, Adams RJ, Kesler KL, et al; SWiTCH Investigators. Magnetic resonance imaging/angiography and transcranial Doppler velocities in sickle cell anemia: results from the SWiTCH trial. Blood 2014;124: 891-98 CrossRef Medline

2. Adams RJ, McKie VC, Hsu L, et al. Prevention of a first stroke by transfusions in children with sickle cell anemia and abnormal results on transcranial Doppler ultrasonography. N Engl J Med 1998; 339:5-11 CrossRef Medline

3. Arkuszewski M, Krejza J, Chen R, et al. Sickle cell disease: reference values and interhemispheric differences of nonimaging transcranial Doppler blood flow parameters. AJNR Am J Neuroradiol 2011; 32:1444-50 CrossRef Medline

4. Oguz K, Golay X, Pizzini FB, et al. Sickle cell disease: continuous arterial spin-labeling perfusion MR imaging in children. Radiology 2003;227:567-74 CrossRef Medline

5. Arkuszewski M, Krejza J, Chen R, et al. Sickle cell anemia: reference values of cerebral blood flow determined by continuous arterial spin labeling MRI. Neuroradiol J 2013;26:191-200 CrossRef Medline

6. Prohovnik I, Hurlet-Jensen A, Adams R, et al. Hemodynamic etiology of elevated flow velocity and stroke in sickle-cell disease. J Cereb Blood Flow Metab 2009;29:803-10 CrossRef Medline

7. Doepp F, Kebelmann-Betzing C, Kivi A, et al. Stenosis or hyperperfusion in sickle cell disease: ultrasound assessment of cerebral blood flow volume. Ultrasound Med Biol 2012;38:1333-38 CrossRef Medline

8. Helton KJ, Glass JO, Reddick WE, et al. Comparing segmented ASL perfusion of vascular territories using manual versus semiautomated techniques in children with sickle cell anemia. J Magn Reson Imaging 2015;41:439-46 CrossRef Medline

9. Gevers S, Nederveen AJ, Fijnvandraat K, et al. Arterial spin labeling measurement of cerebral perfusion in children with sickle cell disease. J Magn Reson Imaging 2012;35:779-87 CrossRef Medline

10. Varela M, Petersen ET, Golay X, et al. Cerebral blood flow measurements in infants using look-locker arterial spin labeling. J Magn Reson Imaging 2015;41:1591-600 CrossRef Medline

11. Wu WC, St Lawrence KS, Licht DJ, et al. Quantification issues in arterial spin labeling perfusion magnetic resonance imaging. Top Magn Reson Imaging 2010;21:65-73 CrossRef Medline

12. Hales PW, Kirkham FJ, Clark CA. A general model to calculate the spin-lattice (T1) relaxation time of blood, accounting for haematocrit, oxygen saturation and magnetic field strength. J Cereb Blood Flow Metab 2016;36:370-74 CrossRef Medline

13. Lu H, Clingman C, Golay X, et al. Determining the longitudinal relaxation time (T1) of blood at 3.0 Tesla. Magn Reson Med 2004;52: 679-82 CrossRef Medline

14. Alsop DC, Detre JA, Golay X, et al. Recommended implementation of arterial spin-labeled perfusion MRI for clinical applications: a consensus of the ISMRM perfusion study group and the European consortium for ASL in dementia. Magn Reson Med 2015;73:102-16 CrossRef Medline

15. De Vis JB, Hendrikse J, Groenendaal F, et al. Impact of neonate haematocrit variability on the longitudinal relaxation time of blood: implications for arterial spin labelling MRI. Neuroimage Clin 2014;4:517-25 CrossRef Medline

16. Varela M, Hajnal JV, Petersen ET, et al. A method for rapid in vivo measurement of blood T1. NMR Biomed 2011;24:80-88 CrossRef Medline

17. Zhang X, Petersen ET, Ghariq E, et al. In vivo blood T(1) measurements at 1.5 T, 3 T, and 7 T. Magn Reson Med 2013;70:1082-86 CrossRef Medline

18. $\mathrm{Wu} \mathrm{WC}$, Jain $\mathrm{V}, \mathrm{Li} \mathrm{C}$, et al. In vivo venous blood $\mathrm{T} 1$ measurement using inversion recovery true-FISP in children and adults. Magn Reson Med 2010;64:1140-47 CrossRef Medline

19. Shimada K, Nagasaka T, Shidahara M, et al. In vivo measurement of longitudinal relaxation time of human blood by inversion-recovery fast gradient-echo MR imaging at 3T. Magn Reson Imaging Sci 2012; 11:265-71 CrossRef Medline

20. Hollowell J, van Assendelft O, Gunter E, et al. Hematological and ironrelated analytes: reference data for persons aged 1 year and over: United States, 1988-94. Vital Health Stat 11 2005;247:1-156 Medline

21. Tripette J, Alexy T, Hardy-Dessources M, et al. Red blood cell aggregation, aggregate strength and oxygen transport potential of blood are abnormal in both homozygous sickle cell anemia and sickle-hemoglobin C disease. Haematologica 2009;94:1060-65 CrossRef Medline

22. Jain V, Duda J, Avants B, et al. Longitudinal reproducibility and accuracy of pseudo-continuous arterial spin-labeled perfusion MR imaging in typically developing children. Radiology 2012;263: 527-36 CrossRef Medline

23. Hales PW, Kawadler JM, Aylett SE, et al. Arterial spin labeling characterization of cerebral perfusion during normal maturation from late childhood into adulthood: normal "reference range" values and their use in clinical studies. J Cereb Blood Flow Metab 2014;34: 776-84 CrossRef Medline

24. van der Land V, Hijmans CT, de Ruiter M, et al. Volume of white matter hyperintensities is an independent predictor of intelligence quotient and processing speed in children with sickle cell disease. Br J Haematol 2015;168:553-56 CrossRef Medline

25. Mutsaerts HJ, van Osch MJ, Zelaya FO, et al. Multi-vendor reliability of arterial spin labeling perfusion MRI using a near-identical sequence: implications for multi-center studies. Neuroimage 2015; 113:143-52 CrossRef Medline

26. Gevers S, Heijtel D, Ferns SP, et al. Cerebral perfusion long term after therapeutic occlusion of the internal carotid artery in patients who tolerated angiographic balloon test occlusion. AJNR Am J Neuroradiol 2012;33:329-35 CrossRef Medline

27. Heijtel DF, Mutsaerts HJ, Bakker E, et al. Accuracy and precision of pseudo-continuous arterial spin labeling perfusion during baseline and hypercapnia: a head-to-head comparison with ${ }^{15} \mathrm{O}_{2} \mathrm{O}$ positron emission tomography. Neuroimage 2014;92:182-92 CrossRef Medline

28. Herscovitch P, Raichle ME. What is the correct value for the brainblood partition coefficient for water? J Cereb Blood Flow Metab 1985; 5:65-69 CrossRef Medline

29. Aslan S, Xu F, Wang PL, et al. Estimation of labeling efficiency in pseudocontinuous arterial spin labeling. Magn Reson Med 2010;63: 765-71 CrossRef Medline

30. Vent-Schmidt J, Waltz X, Romana M, et al. Blood thixotropy in patients with sickle cell anaemia: role of haematocrit and red blood cell rheological properties. PLoS One 2014;9:e114412 CrossRef Medline

31. Connes P, Coates TD. Autonomic nervous system dysfunction: implication in sickle cell disease. CR Biol 2013;336:142-47 CrossRef Medline

32. Brandão MM, Fontes A, Barjas-Castro ML, et al. Optical tweezers for measuring red blood cell elasticity: application to the study of drug response in sickle cell disease. Eur J Haematol 2003;70:207-11 CrossRef Medline

33. Hebbel RP, Yamada O, Moldow CF, et al. Abnormal adherence of sickle erythrocytes to cultured vascular endothelium: possible mechanism for microvascular occlusion in sickle cell disease. J Clin Invest 1980;65:154-60 CrossRef Medline

34. Prengler M, Pavlakis SG, Prohovnik I, et al. Sickle cell disease: the neurological complications. Ann Neurol 2002;51:543-52 CrossRef Medline

35. Kiihne S, Bryant RG. Protein-bound water molecule counting by resolution of $(1) \mathrm{H}$ spin-lattice relaxation mechanisms. Biophys $J$ 2000;78:2163-69 CrossRef Medline

36. Strouse JJ, Cox CS, Melhem ER, et al. Inverse correlation between cerebral blood flow measured by continuous arterial spin-labeling (CASL) MRI and neurocognitive function in children with sickle cell anemia (SCA). Blood 2006;108:379-81 CrossRef Medline

37. van den Tweel XW, Nederveen AJ, Majoie CB, et al. Cerebral blood flow measurement in children with sickle cell disease using continuous arterial spin labeling at 3.0-Tesla MRI. Stroke 2009;40:795-800 CrossRef Medline

38. Lotz J, Meier C, Leppert A, et al. Measurement with imaging: basic facts and implementation. Radiographics 2002;22:651-71 CrossRef Medline

39. Spilt A, Box FM, van der Geest RJ, et al. Reproducibility of total cerebral blood flow measurements using phase contrast magnetic resonance imaging. J Magn Reson Imaging 2002;16:1-5 CrossRef Medline

40. Ambarki K, Wahlin A, Zarrinkoob L, et al. Accuracy of parenchymal cerebral blood flow measurements using pseudocontinuous arterial spin-labeling in healthy volunteers. AJNR Am J Neuroradiol 2015;36:1816-21 CrossRef Medline 